Ekonomi

\title{
Kirlilik Emisyonu ve Doğrudan Yabancı Sermaye Yatırımları: Türkiye İçin "Kirlilik Sığınağı Hipotezi” Testi
}

\author{
Ahmet ŞAHINÖZ \\ asahinoz@hacettepe.edu.tr
}

Zahra FOTOUREHCHI

z.faturechi@yahoo.com

\section{Foreign Direct Investments and Pollution Emissions: "Pollution Haven Hypothesis" Test for Turkey}

\begin{abstract}
In this study, the relationship between foreign direct investment in Turkey and $\mathrm{CO}_{2}$ emissions for the validity of "Pollution Haven Hypothesis" between 1974 and 2011 is examined. Moreover, by examining the impact of increase in the scale of economy and structural changes on $\mathrm{CO}_{2}$ emissions, "the Factor Endowment Hypothesis" will be tested to verify its validity in this context. Based on the empirical results, increment in the scale of economy and structural changes cause increase in $\mathrm{CO}_{2}$ emission, thus Factor Endowment Hypothesis is verified to be valid. However, it can be seen that structural changes have more effects on $\mathrm{CO}_{2}$ emission compared to that of the increase in the scale of economy. Moreover, the decrease in $\mathrm{CO}_{2}$ emission caused by foreign direct investments gives strong support to the view of the critics of Pollution Haven Hypothesis. The findings that there is a positive relationship between existence of time trend, which is found to be statistically significant, and $\mathrm{CO}_{2}$ emission point out that sophisticated technologies have not been used in manufacturing industries and that the society have not been well informed on environmental issues over time.

Keywords

\section{JEL Classification Codes $\quad$ : $\quad$ Q53, Q56, F21.}

: Foreign Direct Investment, Environment, Pollution Haven, Factor Endowment.

\section{Özet}

Bu çalışmada 1974-2011 dönemi için Türkiye'de doğrudan yabancı sermaye yatırımları ve $\mathrm{CO}_{2}$ emisyonu arasındaki ilişkinin “Kirlilik Sığınağı Hipotezi”ne göre geçerliliği incelenecektir. Ayrıca ekonomide ölçek artışı ve yapısal değişimlerin $\mathrm{CO}_{2}$ emisyonu üzerindeki etkisi saptanarak "Faktör Donanım Hipotezin"nin geçerliliği de sınanacaktır. Ampirik sonuçlara gore, ekonominin ölçeğinin artışı ve yapısal değişimler $\mathrm{CO}_{2}$ emisyonunun artmasına neden olmakta ve böylece faktör donanım hipotezi doğrulanmış olmaktadır. Ancak yapısal değişimlerin, ekonomi ölçeğinin artışına göre, $\mathrm{CO}_{2}$ 'yi daha yüksek oranda etkilediği görülmektedir. Ayrıca doğrudan yabancı sermaye yatırımlarının $\mathrm{CO}_{2}$ emisyonunu azaltması kirlilik sığınağı hipotezi eleştiricilerinin görüşlerini doğrulamaktadır. Modelde zaman trendinin istatistikî açıdan anlamlı çıkması ve $\mathrm{CO}_{2}$ emisyonuyla pozitif bir ilişkide bulunması, imalat sanayi üretiminde gelişmiş teknolojilerin kullanılmadığını ve toplumun zaman içerisinde çevre konusunda yeterince bilgilendirilmediğini göstermektedir.
\end{abstract}


Ahmet ŞAHINÖZ \& Zahra FOTOUREHCHI 


\section{Giriş}

Chenery ve Bruno (1962), Mckinnon (1964), Chenery ve Strout (1966) vs gibi iktisatçıların yaptıkları çalışmaların ardından, iktisadi gelişme sürecinde uluslararası ticari kısıtlamaların ve doğrudan yabancı sermaye yatırımlarının rolü konusu, çoğu araştırmacıların ilgi odağı olmuştur. $\mathrm{Bu}$ doğrultuda son 30-40 yıldır yapılmış olan araştırmalardan elde edilen sonuçlara göre, doğrudan yabancı sermaye yatırımları (DYSY) ülkelerin karşılaştırmalı üstünlüğünün optimal kullanımına, firmaların teknoloji ve yönetim yetenekleri ile işgücünün verimliliğinin artmasına, ayrıca ulusal gelirin, tasarrufun ve net ihracatın artmasıyla birlikte ödemeler dengesinin iyileşmesine, ulusal paranın değerinin artmasına ve nihayet ekonomik büyümenin hızlanmasına olanak sağlamaktadır. Çokuluslu firmalar tarafından yerli pazarların elde edilmesi, taşıma maliyetlerinin en aza indirilmesi ve ticari kısıtlamalardan kurtulmak hedefleniyorsa, yapılan yatırım yatay DYSY, eğer global pazarlar hedefleniyorsa, üretim faktörleri açısından maliyetleri en aza indirecek üretim mekanlarında yapılan yatırımlar dikey DYSY diye adlandırılmaktadır (Alsan vd., 2006: 616). Hem yatay hem de dikey DYSY' da çokuluslu firmaların, yatırım ve üretim maliyetlerine çevre maliyetini de eklemeleri gerekmektedir. Zira dünyamızda son yarım asırdır, başta sanayileşme ve kentleşmeye bağlı olarak artan çevre tahribatının toplumlarda oluşturduğu çevre duyarlılığı, uluslararası ticaret ve doğrudan yabancı sermaye hareketlerindeki serbestleşme sürecinde ortaya çıkan çevre maliyetinin varlı̆̆ını ister istemez gündeme taşımış bulunmaktadır.

Ticaret teorilerine DYSY açısından bakılırsa, faktör donanımı yoğunlu üstünlüğüne dayanan Samuelson-Heckscher-Ohlin ve Richardo-Viner modellerinde az miktarda üretim faktörünün (az miktarda sermaye - niteliksiz işgücünün) ülkeler arasında çok kolay ve çok miktarda, sermaye - nitelikli işgücünün çok zor hareket ettiği varsayılmıştır. Ancak her iki modelin analizlerinde çevre sorunları göz ardı edilmiştir. Oysa gelişmiş ülkelerde çevre maliyeti uzun zamandan beri üretim maliyetinin ihmal edilmeyecek bir kısmını kapsamaktadır. Küreselleşmenin şiddetlendirdiği rekabetten dolayı çokuluslu firmalar, çevre maliyeti de dâhil olmak üzere, yüksek kaliteden ödün vermeden üretim maliyetlerini azaltabilen üretim yöntemlerinin arayışı içerisindedirler. Ancak bu arayışlardan her zaman olumlu ya da istenilen düzeyde sonuçlar alınamamaktadır. Bu sefer söz konusu firmalar, doğrudan yabancı sermaye yatırımları yoluyla üretimlerinin coğrafi mekânlarını, çevre politikalarının daha gevşek ve çevre standartlarının daha düşük olduğu ülkelere doğru kaydırmak suretiyle üretim maliyetlerini azaltmaya çalışmaktadırlar. Demek ki çevre kirliliğine kayıtsızlık, gelişmekte olan ülkelere bir anlamda yatırım avantajı sağlamış olmaktadır. Firmaların söz konusu eylemi "Kirlilik Sığınağı Hipotezi” (KSH) olarak adlandırılmaktadır. Doğrudan yabancı sermaye yatırımları ve kirlilik emisyonu ilişkisi işte bu bağlamda araştırma konusunu oluşturmaktadır. Bu çalışmada, bu ilişkinin yani KSH' nin geçerliliği, Türkiye’de 1974- 
2011 yıllarını kapsayan dönem için incelenecektir. Ayrıca ekonomide ölçek artışının ve yapısal değişimlerin kirlilik emisyonu üzerindeki etkisi incelenerek "Faktör Donanım Hipotezi”nin (FDH) geçerliliği de sinanacaktır.

\section{Kirlilik Sığınağı ve Faktör Donanım Hipotezi Etkileri}

KSH'ne göre ülkelerin temel karşılaştırmalı üstünlügünü, çevre politikalarındaki gevşeklik ve katılık dereceleri belirlemektedir. Gelişmiş ülkelerde, gelişmekte olan ülkelere göre daha katı çevre politikalarının uygulandığı bilinmektedir. Genel olarak gelişmiş ülkeler, kirlilik-yoğunluğu yüksek olan endüstriyel üretimlerini gelişmekte olan ülkelere kaydırarak kirliliği kendi ülkelerinden gelişmekte olan ülkelere aktarmış olurlar. Temiz çevreye olan duyarlılık ve talebin düşük olduğu gelişmekte olan ülkelerin sahip olduğu yetersiz ulusal gelir düzeyi de yaygın bir çevre standardı ile denetim mekanizmasının maliyetini karşılamaktan zaten uzaktır. Ancak bu ülkelerde hızlı nüfus artışı, kırsal göç ve çarpık kentleşmenin yarattığı çevre kirliliğinin, KSH çerçevesinde gerçekleşen yatırımlarla daha da arttı̆̆ını söylemek yanlış olmaz.

$\mathrm{Bu}$ arada Kirlilik Sığınağı Hipotezi (KSH) ve Kirlilik Sığınağı Etkisi (KSE) arasında ayrım yapılması gerekmektedir. Kirlilik sığınağı etkisinde ülkeler arasında çevre politikalarındaki farklılık, fabrikaların kuruluş mekânlarını belirleyen ve ticari hareketleri etkileyen en önemli faktördür. Oysa kirlilik sığınağı hipotezi, kirlilik-yoğunluğu yüksek endüstrilerin mevcut üretim yerlerini, katı çevre politikaları olan ülkelerden gevşek çevre politikaları olan ülkelere taşımakla ilgilidir. Yani KSE, üretimde kuruluş mekânının seçilmesi, KSH ise kurulmuş olan üretim mekânının değiştirilmesi üzerinde etkilidir. Uluslararası ticarette kirlilik sığınağ 1 etkisi, hipotezine göre çok daha fazla önem taşımaktadır. Çünkü fabrikaların yer değiştirmesi ekstra bir maliyet gerektirmektedir. (Copland ve Taylor, 2004: 35). Uluslararası piyasalarda oluşan rekabetten dolayı bazı az gelirli ülkeler bilinçli olarak çevre politikalarını gevşetip kirli yabancı yatırımları kendi ülkelerine çekmeye çalışmaktadırlar ki buna aşağıya doğru rekabet (Race of Bottom) denilmektedir. KSH'de ise, uygulanan düşük standartlı çevre politikaları kendiliğinden bir üstünlük yaratmaktadır (Porter \& Gareth, 1999: 135-145). Bir başka anlatımla, ilgili ülkeler gevşek çevre politikalarının kirli yabancı yatırımların girişini özendirdiğinin her zaman farkında olamayabilirler de.

Çevre kirliliği sorunu ve buna bağlı çevre politikalarının ihmal edildiği bir ortamda, uluslararası yatırımların mekânsal dağılımında kirlilik sığınağı hipotezi değil, faktör donanım hipotezi (FDH) geçerlidir. Çünkü FDH'ne göre, ülkelerin karşılaştırma üstünlüğünün belirlenmesinde çevre politikalarının yerine teknoloji ve üretim kaynakları donanımı etkili olmaktadır. Ayrıca bu hipoteze göre, semaye-yoğun mal da kirlilik-yoğun mal anlamına gelmektedir (Copland ve Taylor 2003). Hecksher-Ohlin (HO) teorisine göre, her ülke faktör yoğunluğu yüksek olan malı daha düşük maliyetle ve yüksek kaliteyle 
üretip ihraç edecektir. HO teorisine dayalı FDH'ne göre, gelişmekte olan ülkeler sermaye ve kirlik-yoğunluğu az olan malları, gelişmiş ülkeler ise sermaye ve kirlilik-yoğunluğu yüksek olan malları ihraç edeceklerdir. Kirlilik emisyonu FDH ve KSH'inde birbirinden farklı olacaktır. FDH'ne göre, kirlilik gelişmiş ülkelerde artp ve gelişmekte olan ülkelerde azalacaktır. Ancak bundan sonra KSH devreye girerek gelişmiş ülkelerde gelirin artışıyla birlikte temiz çevreye duyarlılık ve talebin artışıyla (çevre kalitesi lüks bir maldır) oluşacak sosyal baskılar nedeniyle uygulanacak katı çevre politikalarından dolayı bu ülkeler kirli endüstrilerinin üretim yerlerini değiştirip, gevşek çevre politikaları uygulanan gelişmekte olan ülkelere doğru kaydırırken, kendileri sermaye ve kirlilik-yoğunluğu az olan malların üretimine yönelecekler ve sonuçta kirlilik gelişmiş ülkelerde azalırken gelişmekte olan ülkelerde artacaktır. Çevre politikalardaki gevşeklik derecesinden dolayı gelişmekte olan ülkelerin sahip oldukları karşılaştırmalı üstünlük sermaye ve kirlilikyoğun mallara, gelişmiş ülkelerin karşılaştırmalı üstünlüğü ise sermaye ve kirlilikyoğunluğu az olan mallara yönelecektir. Böylece ülkelerin karşılaştırma üstünlükleri ve ticari hareketleri yer değiştirecektir. Söz konusu hipotezler grafikler yardımıyla aşağıda açıklanmaktadır.

\section{Grafik: 1}

\section{Üretim Kaynaklı Kirlilik Emisyonuna Göre FDH ve KSH}

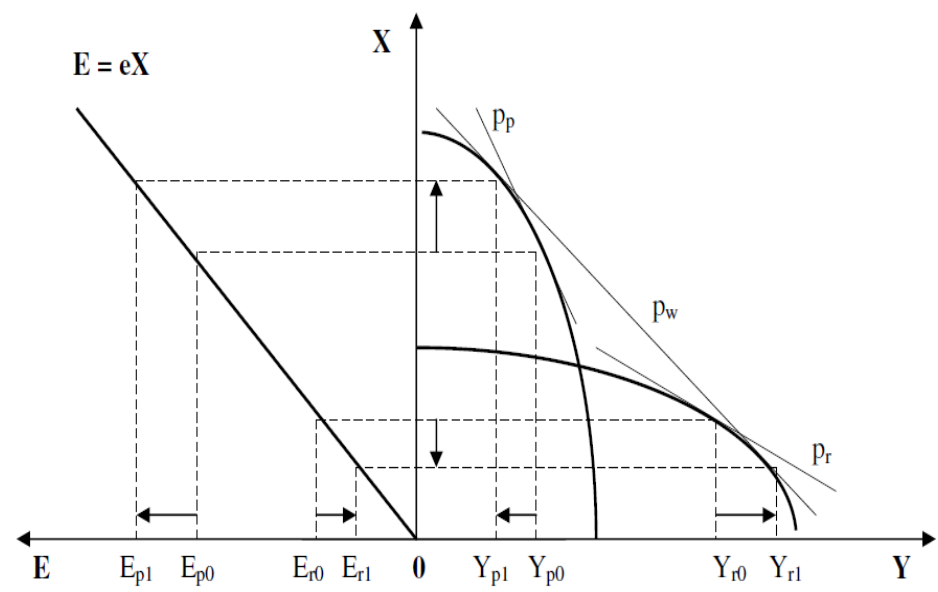

Kaynak: Umed Temurshoev, 2006: 12.

Grafik: 1'de yer alan X kirlilik-yoğun malın ve $\mathrm{Y}$ temiz-malın simgesidir. e kirlilik yoğunluğu ve $(\mathrm{E}=\mathrm{eX})$ sadece üretimden kaynaklanan toplam kirlilik emisyonu, $\mathrm{P}$ yoksul (gelişmekte olan) ve $\mathrm{r}$ zengin (gelişmiş) ülke, $\mathrm{P}_{\mathrm{p}}$ ve $\mathrm{P}_{\mathrm{r}}$ sırasıyla yoksul ve zengin 
ülkelerde üretilen malların yurt içi fiyatı, $\mathrm{P}_{\mathrm{w}}$ her iki ülkede üretilen malların dünya fiyatının simgeleri olarak tanımlanmıştır. Kirlilik-yoğun malın fiyatı, gelişmekte olan ülkede gelişmiş ülkeye göre daha azdır $\left(\mathrm{p}_{\mathrm{p}}^{\mathrm{x}}<\mathrm{p}_{\mathrm{r}}^{\mathrm{x}}\right)$. Çünkü gelişmekte olan ülkede çevre politikalarının katılık derecesi ve kirli malların üretimine ödenen vergi miktarı daha azdır (çevre politikası üstünlüğü). Temiz malın fiyatı sabit tutulursa, temiz malın kirli malın fiyatına oranı gelişmekte olan ülkede gelişmiş ülkeye göre daha yüksek olacaktır: $\left(\mathrm{P}_{\mathrm{p}}=\mathrm{p}_{\mathrm{p}}^{\mathrm{y}} /\right.$ $\mathrm{p}_{\mathrm{p}}^{\mathrm{x}}>\mathrm{p}_{\mathrm{r}}=\mathrm{p}_{\mathrm{r}}^{\mathrm{y}} / \mathrm{p}_{\mathrm{r}}^{\mathrm{x}}$ ). Bu oran aslında üretim olanakları eğrisinin eğimini, yani malların firsat maliyetini göstermektedir. Söz konusu eğri, gelişmiş ülkede gelişmekte olan ülkeye göre daha yatay durumdadır. Sadelik amacıyla grafikte eşürün eğrileri çizilmemiştir. Kapalı bir ekonomide, temiz mal ilk başta gelişmiş ülkede gelişmekte olan ülkeye göre daha çok üretilmektedir $\left(\mathrm{Y}_{\mathrm{r} 0}>\mathrm{Y}_{\mathrm{p} 0}\right)$ ve kirlilik emisyonu daha azdır $\left(\mathrm{E}_{\mathrm{p} 0}>\mathrm{E}_{\mathrm{r} 0}\right)$. Gelişmekte olan ülkede ise bu durumun tam tersi geçerlidir $\left(\mathrm{X}_{\mathrm{r} 0}<\mathrm{X}_{\mathrm{p} 0}\right)$.

Açık bir ekonomide ise ticaretle birlikte gelişmekte olan ülke mevcut dünya fiyatından temiz malı ve gelişmiş ülke kirli malı ithal edecek, gelişmekte olan ülkede kirli mal üretimi ile birlikte kirlilik emisyonu gelişmiş ülkeye göre daha da artacaktır $\left(\mathrm{E}_{\mathrm{p} 1}>\mathrm{E}_{\mathrm{p} 0}\right)$. Gelişmiş ülkelerde bunun tam tersi bir süreç gerçekleşecektir $\left(\mathrm{E}_{\mathrm{r} 1}<\mathrm{E}_{\mathrm{r}}\right)$. Bu durum KSH'nin ortaya koyduğu bir sonuçtur. Bir an için ülkelerin karşılaştırmalı üstünlüklerinin belirlemesinde çevre politikaları yerine kaynak ve teknoloji farklılıklarını koyacak olursak, bu durumda gelişmekte olan ülke ile gelişmiş ülke yer değiştirecek, Y temiz malı gelişmekte olan ülke ve $\mathrm{X}$ sermaye ve kirlilik-yoğun malı gelişmiş ülke üretecek, üretim olanağı eğrisi gelişmekte olan ülkede gelişmiş ülkeye göre daha da yatay hale gelecektir. Ticaretle birlikte kirlilik, gelişmiş ülkede gelişmekte olan ülkeye göre daha da artacak ve Grafik: 1 FDH ile uyumlu hale gelecektir (Copeland ve Taylor, 2003).

Yukarıdaki grafikte tüketimden kaynaklanan kirlilik analize dâhil edilmemiştir. Söz konusu varsayımların altında kapalı ekonomide tüketimden kaynaklanan kirlilik analize dâhil olursa $\mathrm{X}$ malının tüketim miktarı üretim miktarına eşit olduğundan, yine aynı 1. grafikte olduğu gibi, kirlilik emisyonu gelişmekte olan ülkede gelişmiş ülkeden daha fazla olacak ve KSH de geçerliliğini koruyacaktır. Açık ekonomide ticaretle birlikte malların tüketiminin ve üretiminin miktarı birbirinden farklı olacağından, kirlilik emisyonu miktarı doğal olarak birinci grafikle aynı olmayacaktır.

Grafik: 2; açık ekonomi, aynı tüketim tercihleri ve tüketimden kaynaklanan kirlilik emisyonu varsayımları altında çizilmiştir. Ticaretle birlikte iki ticari partnerin denge noktası A'dır. Bu noktada kirli ve temiz malların tüketim miktarları sırasıly Xc ve Yc dir. Eğer her iki ülkede tüketim fazlalı̆̆ ihraç edilirse, gelişmekte olan ülke kirli malı ihraç edip ve temiz malı ithal edecek, gelişmiş ülke ise bunun tersini yapacaktır. Grafik: 2 'de gelişmiş ülkede ticaretle birlikte kirli mal ithalatı temiz mal ihracatından daha fazla olduğundan, gelişmiş ülkede kirli mal tüketiminde ticaret öncesine göre bir artış meydana gelmektedir. Böylece tüketim kaynaklı kirlilik emisyonu yoğunluğu gelişmiş ülkede $\mathrm{E}_{\mathrm{ro}}$, den $\mathrm{E}_{\mathrm{c}}$ ' ye yükselirken gelişmekte olan ülkede $\mathrm{E}_{\mathrm{po}}{ }^{\prime}$ den $\mathrm{E}_{\mathrm{c}}{ }^{\prime}$ ye gerileyecektir. $\mathrm{Bu}$ 
durumda KSH etkisini kaybedip ve Grafik: 2'de FDH geçerli hale gelmektedir. Ayrıca Grafik: 2'de üretim ve tüketim kirlilik emisyonlarının yoğunlukları aynı miktarda olduğu varsayılmıştır. Eğer söz konusu kirlilik yoğunluğu miktarı farklı olsaydı tüketim ve üretimin yarattığı kirlilik için iki farklı doğru çizilmesi gerekecektir. Gerçek dünyada tüketim ve üretimin yaratığı kirlilik yoğunlukları farklı olduğu için, yapılan değişik ampirik çalışmalarda ticaretle birlikte kirliliğin artabilmesi-azalabilmesi ya da hiç değişmemesi mümkün olabilecektir.

Grafik: 2

Tüketim Kaynaklı Kirliliğe göre FDH ve KSH

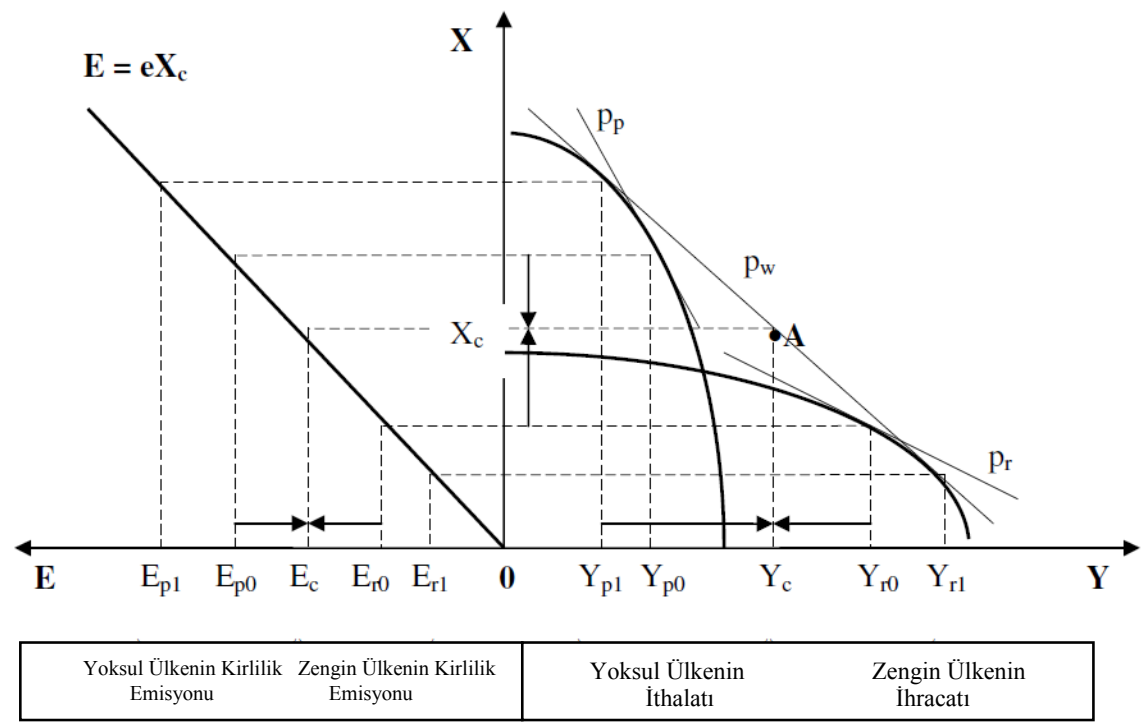

Kaynak: Umed Temurshoev, 2006: 14.

\section{3. Çevre Kirliliğinin Ekonomik Etkilerine Üç Farklı Yaklaşım}

Ticaret, büyüme ve doğrudan yabancı sermaye yatırımları ile çevre arasındaki ilişkiyi incelemek amacıyla çok sayıda teorik ve ampirik araştırma yapılmıştır. Bu araştırmaları üç gruba ayırabiliriz. Birinci grupta, endüstrilerin kirli ve zehirleyici emisyonlarının yoğunluğunun farkına göre veya katma değerlerine eklenen kirlilik maliyetine göre kirli ve temiz endüstri kategorileri yer almaktadır. Bu araştırmalarda regresyon analizi kullanılmakta ve açıklayıcı değişken genellikle ticari serbestlik endeksi, milli gelir büyüme hızı ve benzer değişkenler olmaktadır. Bu araştırmaların içinde Low ve 
Yeats (1992), Lucas vd., (1992), Mani ve Wheeler (1997), Xu (1999) gibi çalışmalar görülmektedir. Bu grupta Yeats (1992) ve Lucas vd., (1992) gibi araştırmalar, gelişmiş ve gelişmekte olan ülkelerde kirlilik-yoğun malların ihracatının azalışı-artışı yoluyla KSH'ni doğrulamışlardır. Bazı araştırmalar ise, gelişmiş ve gelişmekte olan ülkelerde imalat endüstirinin üretim ölçeğinin azalış-artışına bakarak ticaret hareketlerinin HOV teorisiyle çakıştığını ve KSH'yle uyumlu olduğunu göstermişlerdir (Mani ve Wheeler, 1997). Ayrıca ülkelerin çevre standartlarının artmasının ve politikalarının katılaşmasının (ESGs) malların (Environmentally Sensitive Goods) - her birim üretiminin kirlilik maliyetinin yüksek olduğu mallar, başka bir ifadeyle kirli mallar- rekabet güçleri üzerindeki etkisini inceleyen ve kirlilik-yoğun malların ihracatının değişmediğini ortaya koyan araştırmalar da mevcuttur (Xu, 1999). Birinci grup araştırmalarda ülkelerarası kirlilik yoğunluğunun değişmesini kirli mallar politikasının değişmesi yoluyla göstermek aslında pek etkin bir endeks değildir. $\mathrm{Bu}$ araştırmalarda teknolojik değişim ve kirliliği etkileyen diğer faktörler göz ardı edilmiştir. Böyle bir durumda da kirlilik-yoğun malların üretiminin artışıla birlikte kirlilik düzeyi artıp-azalır ya da değişmeyebilir. Ayrıca Cadarso vd., 2010, Cristea vd., 2011 araştırmalarına göre, yapılan araştırmaların çoğunda nihai malların üretimi için birincil ve ara mallarının taşımasından oluşan kirlilik emisyonu göz ardı edilmiştir.

İkinci grup araştırmalarda ise, çevre politikalarının katılaşmasının etkisi ticaret, doğrudan yabancı yatırım ve üretim mekânlarının değiştirilmesi üzerinde incelenmiştir. $\mathrm{Bu}$ tür araştırmalar, kirlilik sığınağı hipotezi testi olarak adlandırılmıştır. Bu grubun içinde bazı araştırmalar, dışsal çevre politikalarındaki katılaşmanın ticareti, doğrudan yabancı yatırım hareketlerini ve üretim mekanlarını etkilemediğini ve dolayısıyla KSH' nin geçerli olmadığını saptamışlardır (Eskeland ve Harrison, 2003; List vd., 2004; Raspiller ve Riedinger, 2004). Buna karşılık bazı araştırmalar, çevre politikalarını içsel değişken olarak tanımlayarak, ters sonuçlar ortaya koymuşlardır. Bu araştırmalar arasında Tobey (1990), Grossman ve Krueger (1993), Levinson (1996), Antweiler vd., (2001), Dean (2002), Lofdalh (2002), Kellenberg (2009), Chen (2011) gibi çalışmalar bulunmaktadır. Bu grup araştırmalar içerisinde farklı bir bakışla KSH'ni inceleyen çalışmalar da yer almaktadır. Örneğin, Eskeland ve Harrison (1997) çokuluslu firmaların yerli firmalara göre üretimlerinde yeni teknolojiler kullanarak kirlilik-yoğunluğu az enerjilere yöneldiklerini öne sürerek, KSH'ni eleştirip açık ekonomilerde kapalı ekonomilere göre kullanılan yüksek çevre standartlarından dolayı kirlilik-yoğunluğu az olan malların üretildiğini ortaya koymuşlardır.

OECD'nin 1997'de yaptığı araştırmaya göre, doğrudan yabancı sermaye yatırımları hem kirlilik yoğunluğu çok hem de az olan endüstrilerde yapılmakta ve çokuluslu firmalar, rakiplerine karşı uluslararası piyasadaki paylarını kaybetmemek için gevşek çevre politikalar yerine değişmeyen çevre politikaları üstünlüğü olan ülkelerde yatırım yapma eğiliminde olmaktadırlar. Kunce vd., (2002) gevşek çevre politikasının karşılaştırma üstünlüğünün değişken sermayeler için geçerli olduğunu ve sabit sermayesi çok olan firmalar mekan karşılaştırma üstünlüğü yerine zaman karşılaştırma 
üstünlüğünden yararlanmaları gerektiği sonucuna varmışlardır. Xing (1998) kirliliğin sermaye hareketlerini ve kirlilik-yoğun malların hareketini değiştirmesine rağmen bu hareketlerin çevre politikalarının gevşemesinden kaynaklanıp kaynaklanmadığını teşhis etmenin zor olduğunu saptamış bulunmaktadır. Taylor (1994) serbest ticaretten elde edilen dünya gelirinin eşitsiz dağılımından dolayı global kirliliğin artacağı sonucuna vardıktan sonra, 2004'deki çalışmasında doğrudan yabancı sermaye yatırımlarının sadece çevre politikalarının uygulanma şiddeti derecesine bağlı olmadığını, ancak hangi çevre politikası aracının kullanıldığına bağlı olduğunu ortaya koymuştur.

Üçüncü grup araştırmalar ise, farklı Girdi-Çıktı modellerine dayalı olarak serbest ticaretin çevre tahribatı üzerindeki etkisini incelemişlerdir: Gay ve Proops (1993), Wyckoff ve Roop (1994), Hayami vd., (1997), Proops vd., (1999), Lenzen (2001), Machado vd., (2001), Dietzenbacher ve Mukhopadhyay (2004), Mukhopadhyay ve Forssell (2004) bu alanda çalışmalar yapmışlardır.

Genel bir değerlendirme ile çevre politikaları üstünlüğüne dayalı olarak yapılan ampirik araştırmalarda KSH'nin güçlü bir biçimde doğrulanması mümkün görülememektedir. Çünkü çevre politikaları oldukça karmaşı ve çok boyutludur. $\mathrm{Bu}$ politikalar herhangi bir endeksle ölçülse dahi, bu sefer de bir ölçme hatası sorunu ortaya çıkabilmektedir. Diğer yandan, çevre politikalarının katılaşmasını herhangi bir yöntemle ölçülmesi de zor bir işlemdir (Shadbegian ve Wolverton, 2010: 13).

Aslında temel sorun gerekli çevre verilerinin toplamasıyla ilgilidir (Levinson, 2008:1) ve aynı zamanda karmaşık yapısı nedeniyle çevre politikalarının hacminin ölçülmesi de pek basit değildir (Xing ve Kolstad, 2002:3). Çevre politikaları doğru ölçülse de, bir içsel değişken olduğundan dolayı firmaların davranışları, iş ve kariyer güvencesi, bölgesel emniyet, politik faaliyetler vs sayısallaştırılması çok zor değişkenleri içermektedir (Levinson ve Taylor 2008).

Kullanılan kirlilik endekslerinden sözü edilen kirliliğin üretim kaynaklı olduğu çıkarsamasını yapsak da, yukarıda yapılan ampirik araştırmalarda kirliliğin hangi kaynaktan doğduğu konusunda herhangi bir açıklama yapılmadığı görülmektedir. Şunu da hemen belirtelim ki, gerçek yaşamda olsun ampirik çalışmalarda olsun bu ayrımı yapmak pek kolay değildir. Bununla birlikte grafiklerde gösterdiğimiz gibi üretim kaynaklı kirlilik yerini tüketim kaynaklı kirliliğe bırakırsa analiz aracı olarak KSH yerine FDH geçerli olacaktır ve yapılan ampirik çalışmalarda farklı sonuçlara ulaşılabilinecektir.

Yukarıdaki ampirik çalışmalardan yapacağımız araştırmaya yönelik edindiğimiz bir başka deneyim, araştırma modeli seçimi ile ilgilidir. İkinci grup araştırmalarda çevre politikalarının ölçümünün oluşturduğu sorunlardan dolayı doğrudan yabancı sermaye yatırımları ve kirlilik emisyonu arasındaki uzun dönemli ilişki spesifik bir ülke için 
incelenmemiştir. Bu bakımdan Türkiye'de doğrudan yabancı sermaye yatırımları ve kirlilik emisyonunu arasındaki ilişkiyi uzun dönemde incelemeyi amaçlayan araştırmamız birinci grup araştırmaların modeline dayanacak, ayrıca diğer araştırmalar gibi bizim araştırmamızda da kirlilik üretim kaynaklı olacaktır.

\section{Teorik Çerçeve ve Model Özellikleri}

$\mathrm{Bu}$ araştırmada kullanılacak temel teorik model, Hettige, Mani, ve Wheeler (1995) araştırmalarındaki modele dayanmaktadır. İlgili model, Taldudkar ve Meisener (2001) tarafından yapılmış olan bir takım düzenlemelerden sonra şu şekilde yazılabilir:

$P=f(Y, M, K)$

$\mathrm{P}=$ Kirlilik emisyonu, $\mathrm{Y}=$ Çıktı, $\mathrm{M}=$ Fabrika üretimi, $\mathrm{K}=$ Sermaye.

DYSY'nın kirlilik üzerinde etkisini inceleyen ampirik model:

$\mathrm{CO}_{2 \mathrm{t}}=\beta_{0}+\beta_{1} \mathrm{GDP}_{\mathrm{t}}+\beta_{2} \mathrm{MV}_{\mathrm{t}}+\beta_{3} \mathrm{FDI}_{\mathrm{t}}+\varepsilon_{\mathrm{t}}$

$\mathrm{CO}_{2 \mathrm{t}}=\mathrm{CO}_{2}$ 'nun kişi başına düşen metrik ton emisyonu

$\mathrm{GDP}_{\mathrm{t}}=$ Kişi başına düşen gayri safi yurtiçi hâsıla $(\mathrm{GSYH})$

$\mathrm{MV}_{\mathrm{t}}=$ İmalat sanayinin GSYH'deki katma değer payı

$\mathrm{FDI}_{\mathrm{t}}=$ Doğrudan yabancı sermaye yatırımlarının net girişinin GSYH'deki payı

FDH ve KSH'lerine göre $\beta_{1}, \beta_{2},>0, \beta_{3}>0$ olması beklenmektedir.

KSH eleştiricilerine ve FDH'ne göre $\beta_{1}, \beta_{2},>0, \beta_{3}<0$ olması beklenmektedir.

Ekonominin ölçeği ve yapısal değişimleri sırasıyla kişi başına düşen $\mathrm{GSYH}^{1}$ ve imalat sanayinin GSYH'deki katma değer payı ile gösterilmektedir. Sermaye yoğun imalat sanayinde gerçekleştirilen üretim, kirlilik düzeyini artıran en önemli etkenlerden biridir (Mani ve Wheeler, 1998). Elde edilen araştırmaların sonuçlarına göre, en yüksek $\mathrm{CO}_{2}$ salınımına neden olan ve çevre kirliliği yaratan imalat sanayi sektörleri demir-çelik, demir

1 Ekonominin ölçeği, Meisener (2001), Merican vd., (2007), Ridzuan vd., (2012) gibi araştırmalarda da kişi başına düşen GSYH ile gösterilmiştir. 
dışı metaller, kimya sanayi, kâğıt ve kâğıt ürünleri, metal olmayan madeni ürünlerdir (Tobey, 1990; Mani, 1996; Mani ve Wheeler, 1998). Doğrusal modellere göre, gelişmekte olan ülkelerde $\mathrm{GDP}_{\mathrm{t}}$ ve $\mathrm{MV}_{\mathrm{t}}$ 'nin katsayılarının pozitif olması beklenmektedir ve iktisadi gelişmenin ilk aşamasında olan ülkelerde yapısal değişimlerle birlikte üretim ölçeğinde meydana gelen artış, kirlilik emisyonunun artmasına neden olmaktadır (Rock, 1996; Friedl ve Getzner, 2003; Cole, 2004). KSH'ne göre, gevşek çevre politikalarının üstünlüğünden dolayı gelişmiş ülkelerden gelişmekte olan ülkelere kirlilik-yoğun endüstiriler taşınmaktadır. KSH'nin geçerli olduğu durumda FDI katsayısının poziitif olması beklenmektedir (Taludkar ve Meisner, 2001; Letchumanan ve Kodama, 2000). KSH'ni eleştiren yazarlar ise, çokuluslu firmaların yerli firmalara göre üretimlerinde kirlilikyoğunluğu az enerjilere yönelip, yeni teknolojiler kullandıklarından FDI katsayısının negatif olacağını savunmaktadırlar.

\section{Veri Seti ve Ekonometrik Yöntem}

Sağlıklı veri elde edebilmek DYSY ve kirlilik emisyonu arasındaki ilişkinin incelenmesinde büyük önem taşımaktadır. Çalışmada 1974-2011 dönemini kapsayan veriler, Küresel Çevre İzleme Sistemi (Global Envirnoment Monitoring System) ve Dünya Kaynak Enistitüsü (World Resource Institue WRI) tarafından yayınlanan verilerden elde edilmiştir.

Çalışmada kullanılacak olan serilerin öncelikle durağan olup olmadıklarının belirlenmesi gerekmektedir. $\mathrm{Bu}$ nedenle $\mathrm{CO}_{2 t}, \mathrm{GDP}_{\mathrm{t}}, \mathrm{MV}_{\mathrm{t}}$ ve $\mathrm{FDI}_{\mathrm{t}}$ serilerinin birim kök içerip içermediklerini saptamak için Augmented Dickey Fuller (Genişletilmiş Dickey Fuller, ADF) testi, KPSS testi ve serilerdeki kurılmayı dikkate alan Perron (1989) testi yapılmıştır. Çalışmada uygulanan bu üç test literatürde çok fazla kullanıldığından burada testle ilgili teorik açıklama yapılmayacaktır.

Test sonuçları Tablo: 1'de verilmektedir. ADF ve PP testlerinin sonuçlarına göre, tüm serilerin düzeyde birim kök içerdikleri hipotezi, 0.01 anlam düzeyinde reddedilememiştir. KPSS testinin sonuçlarına göre, tüm serilerin 0.05 anlam düzeyinde durağan oldukları hipotezi reddedilmiştir. Değişkenlerin tamamının düzey değerleri durağan değilken, birinci farkları alındığında durağan hale gelmektedirler. Ayrıca zaman verilerinin birim kök testleri sabit terimli ve trendli yapıldığında, KPPS testinin düzey değerinin anlamlılık düzeyi hariç, elde edilen sonuçlar sabit terimli test sonuçlarına yakın bulunmaktadır².

2 Sabit terimli ve trendli zaman verilerinin birim kök test sonuçları ekte verilmiştir. 
Tablo: 1

Zaman Verilerinin Birim Kök Test Sonuçları (Sabit Terimli)

\begin{tabular}{|c|c|c|c|c|c|c|c|}
\hline \multirow{2}{*}{\multicolumn{2}{|c|}{ Değişkenler }} & \multicolumn{2}{|c|}{$\begin{array}{c}\text { ADF Testi } \\
\text { H0:Birim Kök Var }\end{array}$} & \multicolumn{2}{|c|}{$\begin{array}{c}\text { KPSS Testi } \\
\text { H0:Seriler Durağandır }\end{array}$} & \multicolumn{2}{|c|}{$\begin{array}{c}\text { Phillips-Perron Testi } \\
\text { H0:Birim Kök Var }\end{array}$} \\
\hline & & Düzey & Birinci Fark & Düzey & Birinci Fark & Düzey & Birinci Fark \\
\hline \multicolumn{2}{|c|}{$\begin{array}{c}\mathrm{CO}_{2} \text { 'nun kişi başına düşen metrik ton } \\
\text { emisyonu }\end{array}$} & -0.1532 & -6.2734 & $0.7193 * *$ & 0.0741 & -0.02405 & -6.3197 \\
\hline \multicolumn{2}{|l|}{ Kişi başına GSYH } & 0.3164 & -5.9224 & $0.7054 * *$ & 0.1319 & 0.4369 & -5.9263 \\
\hline \multicolumn{2}{|c|}{$\begin{array}{c}\text { İmalat sanayinin GSYH'deki katma değer } \\
\text { payı }\end{array}$} & -1.9595 & -6.6926 & $0.5526 * *$ & 0.3189 & -1.9145 & -6.7015 \\
\hline \multicolumn{2}{|c|}{$\begin{array}{l}\text { Gayri safi doğrudan yabancı sermaye } \\
\text { yatırımları girişinin GSYH'deki payı }\end{array}$} & -1.8224 & -5.0043 & $0.5537 * *$ & 0.2502 & -1.7713 & -6.7292 \\
\hline \multicolumn{4}{|c|}{ ADF ve PP Testlerinde Kritik Değerler } & \multicolumn{4}{|c|}{ KPSS Testinin Kritik Değerleri } \\
\hline \%1 Düzeyinde & \multicolumn{3}{|c|}{-3.62102} & \multicolumn{4}{|c|}{0.73900} \\
\hline \%5 Düzeyinde & \multicolumn{3}{|c|}{-2.94342} & \multicolumn{4}{|c|}{0.46300} \\
\hline \%10 Düzeyinde & \multicolumn{3}{|c|}{-2.61102} & \multicolumn{4}{|c|}{0.34700} \\
\hline
\end{tabular}

***0.01 düzeyinde, $* * 0.05, * 0.1$ düzeyinde anlamlılı̆̆ ifade etmektedir.

Seriler durağan olmadığı durumda sahte regresyon olması ihtimali vardır. Fakat eşbütünleşme sağlandığında tahmin sonuçlarının güvenirliliği artacaktır (Granger, 1987: 251-276). I(1) yapısındaki seriler için eşbütünleşme test edilerek sonuçlar Tablo: 2'de sunulmuştur. Önce Friedel ve Getzner (2003) çalışmasında izlenen yöntem takip edilmiş olup, Denklem 2 tahmin edilerek eşbütünleşme iki aşamada gerçekleşmiştir. İlk adım olarak, Eşitlik 2'deki modelin test sonucu Durbin Watson istatistiğinin sıfırdan istatistikî olarak farklılığı (CRDW) testiyle sınanmıştır ${ }^{3}$. DW istatistiği sıfırdan farklı ise, ikinci aşama testi olarak tahminin hata terimi $\varepsilon_{\mathrm{t}}$ ADF Augmented Dickey Fuller testi aracılığıyla formel olarak sınanacaktır (Fridl ve Getzner, 2003). İkinci aşamada kalıntılarda birim kökün reddedilmesi, eşbütünleşme denkleminin kalıntılarının durağan olduğunun yani eşbütünleşmenin saptandığının göstergesi olmaktadır. Ĕger ilk aşamada hesaplanan d değeri örneğin 0.511 'den küçükse, eşbütünleşme önsınavı \%1 düzeyde reddedilir ve ikinci aşama testi gerçekleşemez. Testin birinci aşamasında Durbin-Watson'nun 1.600'lik değeri vardır ve boş hipotez reddedilemez. İkinci sütün eşbütünleşme analizi daha da önemlidir ve kalıntının durağanlığını formel olarak sınamaktadır. -4.7588 ADF test değeri kalıntılarda birim kök bulunmadığını (\%1 anlamlık düzeyinde) göstermekte ve bundan da

3 CRDW sınaması için BKZ.Sargan ve Bhargava (1983) sınamanın kritik değerleri \%1,\%5 ve \%10 değerleri için 0.511,0.386 ve 0.322 dir (Gujarati,1995,böl.21).Sinama tek başına karar gücüne sahip bir sınama olarak görünmektedir. 
dört zaman serisinin beraber hareket ederek eşbütünleşme gösterdiği sonucuna varılmaktadır. Eşbütünleşme olduğu durumda, Ekk tahmin edicisi en iyi- doğrusalsapmasız tahmin edici özelliklerini korumaktadır.

Tablo: 2

$\mathrm{CO}_{2 \mathrm{t}}$ ve GDP $, \mathrm{MV}_{\mathrm{t}}, \mathrm{FDI}_{\mathrm{t}}$ Serilerinin Arasında Eşbütünleşme Testi

\begin{tabular}{|c|c|c|}
\hline & $\mathrm{CO} 2 \mathrm{t}$ & $\mathrm{d}(\varepsilon \mathrm{t})$ \\
\hline Sabit terim & $-1.0570(-7.4937)^{* * *}$ & - \\
\hline GDPt & $0.0005(30.800) * * *$ & - \\
\hline MVt & $0.0337(4.9724) * * *$ & - \\
\hline FDIt & $-0.0502(-1.8169) *$ & - \\
\hline Et-1 & - & $-0.8014(-4.7588)$ \\
\hline $\mathrm{d}(\varepsilon \mathrm{t})$ & - & $-1.3147(-7.6499)$ \\
\hline Uyarlanmış R2 & 0.98 & - \\
\hline Akaike kriteri & -1.8544 & - \\
\hline Schwarz kriteri & -1.6802 & - \\
\hline F-istatistiği & 837.154 & - \\
\hline Log olabilirlik & 38.3071 & 37.5001 \\
\hline Durbin-Watson & 1.600 & 1.9205 \\
\hline Breusch-Golfrey LM & $1.1538<0.3286>$ & - \\
\hline ADF test & - & -4.7588 \\
\hline Kritik ADF seviyeleri & - & $\begin{array}{l}-3.6267(\% 1) \\
-2.9458(\% 5) \\
-2.6115(\% 10)\end{array}$ \\
\hline $\mathrm{N}$ & 38 & - \\
\hline $\mathrm{HO}$ & Reddedilemez*** & $\operatorname{Red} * * *$ \\
\hline
\end{tabular}

Not: 1 - Parantez içerisindeki değerler t-istatistikleri ve $<>$ içerisindeki değer test olasllık değeridir.

Not: 2 - Bu tablo referans çalışmasında yer aldığı şekliyle hazırlanmıştır.

Not: 3 - ***0.01 düzeyinde, **0.05, *0.1 düzeyinde anlamlıllğ

Tablo: 3

Modelin Tahmin Sonuçlar

\begin{tabular}{|c|c|}
\hline Değişkenler ve Testler & Parametreler ve Değerler \\
\hline GDP & $0.0005(30.800) * * *$ \\
\hline MV & $0.0337(4.9724) * * *$ \\
\hline FDI & $-0.0502(-1.8169) *$ \\
\hline F-istatistiği & 837.1547 \\
\hline $\mathbf{R}^{2}$ & 0.98 \\
\hline Durbin-Watson & 1.6007 \\
\hline
\end{tabular}

***0.01 düzeyinde, $* * 0.05, * 0.1$ düzeyinde anlamlılı̆̆ ifade etmektedir. 
Türkiye'deki doğrudan yabancı sermaye yatırımları ve $\mathrm{CO}_{2}$ emisyonu arasında ilişki belirlenen 2 no'lu modelle, En Küçük Kareler yöntemiyle tahmin edilmiştir. 2 no'lu modelin tahmin sonuçları Tablo: 3 'teki gibidir.

Tahmin sonuçlarına göre, FDI ve diğer MV, GDP değişkenlerinin katsayıları istatistikî olarak sırasıyla $\% 10$ ve $\% 1$ düzeyde anlamlı ve bağımlı değişken olan $\mathrm{CO}_{2}$ üzerinde beklenen teorik etkileriyle yakın sonuçlar bulunmuştur. Modeldeki bağımsız değişkenlerin parametrelerinin birlikte anlamlılığına bakıldığında ise, yüksek bir F değeri söz konusudur. F değerinin yüksek olması ve olasılık değerinin çok düşük olması, bağımsız değişkenlerin birlikte $\mathrm{CO}_{2}$ 'deki değişimi açıklama gücüne sahip olduklarını göstermektedir. Ayrıca $\mathrm{R}^{2}$ ye göre $\mathrm{CO}_{2}$ 'deki değişimlerin \%98'i bağımsız değişkenler tarafından açıklanmaktadır. Son olarak Durbin-Watson istatistiğinin 1.600 değer vermesi ve kararsız bölgede bulunması 1. dereceden ardışık bağımlılığın olup olmadığına dair kesin sonuç vermemektedir.

Şekil: 3

Modelin Hata Terimleri Dağılımı

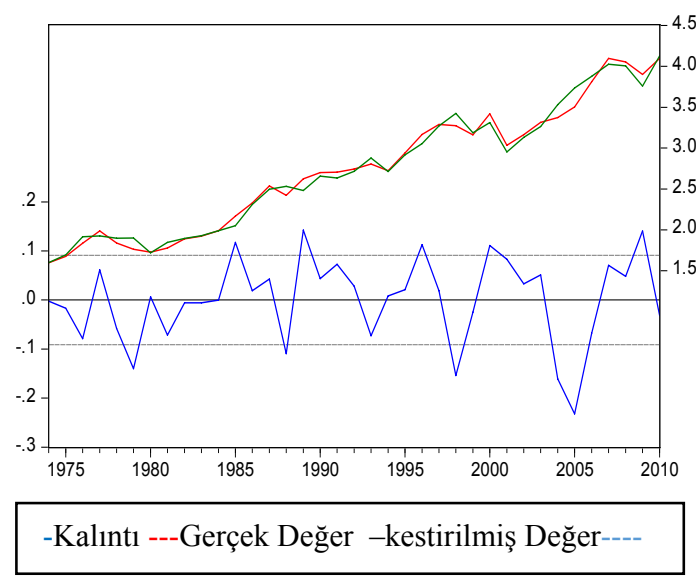


Modelden elde edilen hata terimlerinin dağılımı Şekil: 3'de gösterilmiştir. Bu değerlere bakıldığında da hata terimlerinin bir önceki değerlerinden etkilenmediği görülmektedir. Yani hata terimleri birbirlerinden bağımsız dağılım sergilemektedirler. Ek olarak ardışık bağımlılığı Breusch-Godfrey testiyle sınanmış ve sonuçlar Tablo: 2'nin birinci sütununda verilmiştir. Burada $\mathrm{F}$ istatistiğine göre bir içsel bağıntı problemi tesbit edilmemiştir.

Türkiye'de FDH ve KSH'lerini inceleyen 2 no'lu modelde ardışık bağımlılığın olmamasının yanında, değişen varyans ve çoklu doğrusallığın bulunmaması da modelin açıklayıcılığı açısından önemlidir. Tahmin edicilerin etkinliğini azaltan değişen varyans problemi için White Testi yapıldığında ise şu sonuçlara ulaşılmıştır:

Tablo: 4

Model White Testi Sonuçları

\begin{tabular}{|l|l|}
\hline F-istatistiği 1.5040 & Olasılık değer 0.1968 \\
\hline Obs* R-square 12.3555 & Olasılık değer 0.1940 \\
\hline \multicolumn{2}{|l|}{ H0: Heteroskedastisite (değişen varyans) Yoktur. } \\
\hline
\end{tabular}

Tablo: 4'de gösterilen White Testi sonuçlarına bakıldığında, yüksek olasılık değeriyle anlamlı bir F değeri bulunmamıştır. Bu sonuçlara göre, modelde değişen varyans problemi bulunmamaktadır.

Ayrıca yapılan Jarque-Bera normallik testi, hata teriminin normal dağılımı ile sonuçlanmıştır. Modelde bir spesifikasyon (model kurma) hatası olup olmadığı yönünde yapılan Ramsey RESET testi sonucu, modelde bir spesifikasyon hatası olmadığını göstermektedir.

Tablo: 5

Model Ramsey RESET ve Normallik Testlerinin Sonuçları

\begin{tabular}{|c|c|c|c|}
\hline \multicolumn{2}{|c|}{ Ramsey RESET Testi } & \multicolumn{2}{|c|}{ Jarque-Bera, Normallik Testi } \\
\hline F-istatistiği & 4.012 & Jarque-Bera & 2.2157 \\
\hline Olasılık değeri & 0.125 & Olasılık değeri & 0.3303 \\
\hline H0: Modelde Spesifikasyon (Mod & I Kurma) Hatası Yoktur. & \multicolumn{2}{|c|}{ H0: Hatalar Normal Dağılmaktadır. } \\
\hline
\end{tabular}


Ana kütle katsayılarının tahmin edilmesini güçleştiren bir sorun olan çoklu doğrusallığın olup olmadığının da, modelin güvenilirliği açısından test edilmesi gerekmektedir. Aksi takdirde, çoklu doğrusallığın olması durumunda, bulunan her bir bağımsız değişkenin parametresinin, bağımlı değişken üzerinde kendi net etkisini göstermesi mümkün değildir. 2 no'lu modelde yüksek bir $\mathrm{R}^{2}$ olması ancak anlamsız $\mathrm{t}$ değerlerinin olmaması, modelde çoklu doğrusallığın olmadığına işaret etmektedir. Aynı şekilde, teorik beklentiler ile uyumlu sonuçlar bulunduğundan dolayı da çoklu doğrusallık olmadığı söylenebilir. Çoklu doğrusallık sorununun modelde olup olmadığını anlamak için bir de ikili korelasyonlara bakıldığında şu sonuçlara ulaşılmaktadır:

Tablo: 6

\section{Modeldeki Değiş̧kenlerin Korelâsyon Matrisi}

\begin{tabular}{|l|l|l|l|}
\hline FDI & MV & GDP & \\
\hline 0.51630 & 0.099385 & 1.000000 & GDP \\
\hline-0.135001 & 1.000000 & 0.099385 & $\mathrm{MV}$ \\
\hline 1.000000 & -0.135001 & 0.51630 & FDI \\
\hline
\end{tabular}

Tablo: 4'de bağımsız değişkenler arasında, pozitif veya negatif yönde güçlü bir korelasyon gözükmemektedir. Tablo: 4'te görülen FDI ve GDP arasındaki ilişki, iktisadi değişkenlerin çoğu arasında bulunabilecek güçte bir ilişkidir. $\mathrm{Bu}$ durum çoklu doğrusallığın varlığı için özgün bir neden değildir.

Yapılan diagnostik testler sonucunda modelde hataların normal dağıldığı, 1 . derece otokorelasyon olmadığı, değişen varyans sorununun bulunmadığı ve son olarak da model kurma hatasının olmadığı görülmektedir. Ayrıca regresyon analizine konu değişkenler birim kök içermekle birlikte eşbütünleşiklerdir. Bu bağlamda kurulan model güçlü (robust) bir model olup, modeldeki katsayılar yorumlanabilir niteliktedirler.

Tablo: 3'deki değerlere bakıldığında, 2 no'lu modelde asıl belirleyici bağımsız değişkenler olan GDP, MV ve FDI'ın işaretleri, teorik beklentilere yakındır. Bağımsız değişkenlerden GDP ve MV'nin parametresi istatistikî olarak \%1 düzeyinde anlamlıdır. Diğer bağımsız değişken olan FDI \%10 düzeyinde istatistikî olarak anlamlı sonuç vermektedir. 2 no'lu modelde kullanılan açıklayıcı değişkenlerin istatistikî olarak anlamlı olmalarının yanı sıra, ekonomik olarak da anlamlı ve $\mathrm{CO}_{2}$ emisyonu üzerinde etkin belirleyici güçleri bulunmaktadır. GDP ve MV değişkenlerinin $\% 1$ artışı karşısında $\mathrm{CO}_{2}$ 'de ortalama sırasıla $\% 0.0005$ ve $\% 0.0337$ artış meydana gelmektedir ve FDH doğrulanmaktadır. İktisadi gelişme aşamasında olan Türkiye'de ekonominin ölçeğinin artışı ve sanayileşmenin ve hızlı büyümenin ortaya koyduğu yapısal değişmeler $\mathrm{CO}_{2}$ emisyonun artmasına neden olmaktadır. Ancak burada, yapısal değişimleri temsil eden imalat sanayinin GSYH'deki katma değer payı ekonominin ölçeğinin artışını temsil eden 
kişi başına düşen GSYH'göre, $\mathrm{CO}_{2}$ 'yi daha yüksek oranda etkilediği görülmektedir. Mani ve Wheeler (1998) çalışmasında belirttiği gibi, sermaye yoğun imalat sanayide gerçekleştirilen üretim, kirlilik oranını artıran en önemli etkenlerden biridir ve Türkiye'de imalat sanayinin üretimi GSYH'ye göre kirliliğin artmasında daha çok pay üstlenmektedir. Ekonominin ölçeği ve yapısal değişimleri ile ilgili elde edilen sonuçlar Rock (1996), Friedl ve Getzner (2003), Cole(2004), Merican (2007), Ridzuan, (2012) gibi yapılan birçok araştırmanın sounçlarına yakın bulmaktadır.

Çalışmanın yapısını oluşturan, 2 no'lu modelde kullanılan son açıklayıcı değişken olan FDI'daki \%1 bir artış karşısında ise \%10 anlam düzeyinde $\mathrm{CO}_{2}$ 'de ortalama \%0.0502 azalma meydana gelmektedir. $\mathrm{Bu}$ sonuca dayalı olarak Türkiye'de $\mathrm{KSH}$ doğrulanmamaktadır. Böylece Türkiye için doğrudan yatırım yapan yabancı firmaların yerli firmalara göre üretimlerinde kirlilik-yoğunluğu az enerjilere yöneldiklerini ve yeni teknolojiler kullandıklarını savunan KSH eleştiricilerinin görüssleri doğrulanmaktadır. Ayrıca FDI'ın $\mathrm{CO}_{2}$ emisyonundaki azaltma etkisi, $\mathrm{MV}$ ve GDP'nin $\mathrm{CO}_{2}$ emisyonundaki artırma etkisinden daha güçlü görülmektedir. Türkiye'de FDH'nin doğrulanması, üretim birimlerinin emek-yoğun endüstrilerden sermaye ve kirlilik-yoğun endüstrilere kayması anlamına gelmektedir. Ancak KSH'nin geçeli olmaması bu değişimlerin gevşek çevre politika üstünlüğünden değil de, belki Türkiye gibi gelişmekte olan ülkelerde sanayileşme hareketleri yalnızca emek-yoğun üretim tekniği (tekstil gibi) ile sınırlı kalmayıp, yüksek oranda kirlilik yaratan sermaye yoğun endüstrilere de (petrokimya, çelik gibi) kaymaya başlamasından ileri gelmektedir. Türkiye'de imalat sanayi katma değer payı, kişi başına düşen GSYH'ya göre $\mathrm{CO}_{2}$ 'yi daha yüksek oranda etkilediğinden dolayı, iktisadi büyümeyi sürdürebilmek için, siyasi iktidarların imalat sanayinin üretiminde çevreye karşı duyarlı politikaların uygulanmasını özendirmesi gerekmektedir. Diğer taraftan sürekli bir çevreci yaklaşımla DYY'ın ülkeye çekilmesini sağlayan etkin ekonomi politikalarının uygulanması da ekonomik gelişme için bir zorunluluktur.

Sürdürebilir büyümeye, sadece kirlilik-yoğun malların üretiminde uygulanan çevre dostu politikalarla veya kirlilik-yoğunluğu az DYY'ın ülkeye çekilmesini sağlamakla ulaşmak mümkün değildir. Bunun yanında, toplumda çevresel bilincin arttırılması ve bu amaç doğrultusunda resmi kurumların ve sivil toplum kuruluşlarının etkin işleyişinin sağlanması gerekmektedir. Bu bağlamda, çevresel yönetim sistemleri güçlendirilmelidir. Bölgesel bazda çevre stratejileri geliştirilmeli, bu doğrultuda ekonomik araçlardan uygun bir biçimde yararlanılmalıdır. Çevre koruma ve geliştirme ile ilgili bilgi ve bilincin, her ortamda artırılmasına yönelik çalışmalar yapılmalıdır. Ayrıca kirlilikyoğun malların üretiminde çevre dostu teknolojik gelişmelerden yararlanmak teşvik edilmelidir. Ancak bu araştırmada uygulanan model, birinci grup araştırmalara dayanmaktadır ve bu tür araştırmalar teknolojik gelişmeleri göz ardı etmelerinden dolayı eleştirilmektedir. Oysa zaman içerisinde gerçekleşen teknolojik gelişmeler ve toplumun 
çevre ile ilgili bilgilenmesi sonucunda kirlilik-yoğun malların üretimindeki artış kirlilik düzeyinin artmasını engelleyebilir veya kirlilik düzeyini azaltabilir.

Biz bu araştırmada zaman içerisinde meydana gelen teknolojik gelişmeleri ve toplumun çevre ile ilgili bilgi düzeyinin yükselmesini zaman trendiyle temsil edip ve uygulanan modele zaman trendini ekleyerek yeniden tahminde bulunacağı. Trend, modelde $\mathrm{t}$ ile gösterilmiştir. Tablo: 7'deki tahminlerde trendin etkisi, yani toplumun çevresel bilincinin yükselmesinin ve teknolojik gelişmelerin etkisi görülmektedir. Tablo: 7'de elde edilen sonuçlar Tablo: 3'deki sonuçlara yakın olduğu için detaylı olarak yorumlanmamıştır. Ancak zaman trendinin anlamlı çıkması ve $\mathrm{CO}_{2}$ emisyonuyla pozitif bir ilişki içerisinde olması, Türkiye'de imalat sanayi üretiminde gelişmiş teknolojilerin kullanılmadığını ve toplumun zaman içerisinde çevre ile ilgili bilgilenmesinin yeterince sağlanmadığını göstermektedir.

Tablo: 7

\section{2.no'lu Modelin Trend ile Tahmin Sonuçları}

\begin{tabular}{|c|c|}
\hline Değişkenler ve Testler & Parametreler ve Değerler \\
\hline GDP & $0.00048(8.9303) * * *$ \\
\hline MV & $0.0277(3.8967) * * *$ \\
\hline FDI & $-0.0358(-1.3112) *$ \\
\hline $\mathbf{t}$ & $0.0124(2.0483) * * *$ \\
\hline F-istatistiği & 689.7213 \\
\hline $\mathbf{R}^{2}$ & 0.98 \\
\hline Durbin-Watson & 1.507 \\
\hline
\end{tabular}

\section{Sonuç}

Bu çalışmada çevre kirliliğinin, doğrudan yabancı sermaye yatırımları aracıllı̆ı ile gelişmiş ülkelerden gelişmekte olan ülkelere aktarıldığını savunan ve literatürde "Kirlilik Sığınağı Hipotezi” adı verilen görüşün yanı sıra "Faktör Donanım Hipotezi” de uygulamalı olarak Türkiye'de 1974-2011 yıllarını kapsayan dönem için sınanmıştır. Ulaşılan ampirik sonuçlara göre, Türkiye'de ekonominin ölçeğinin artışı ve yapısal değişimler $\mathrm{CO}_{2}$ emisyonunun artmasına neden olmakta ve böylece faktör donanım hipotezi doğrulanmış olmaktadır. Ayrıca doğrudan yabancı sermaye yatırımlarının $\mathrm{CO}_{2}$ emisyonunu azaltması kirlilik sığınağı hipotezi eleştiricilerinin görüşlerini doğrulamaktadır. 
Zaman trendinin anlamlı çıkması ve $\mathrm{CO}_{2}$ emisyonu ile pozitif bir ilişki içerisinde bulunması, imalat sanayi üretiminde gelişmiş teknolojilerin kullanılmadığını ve toplumun zaman içerisinde çevre ile ilgili bilgilenmesinin yeterince sağlanmadığını göstermektedir.

Türkiye'de FDH'nin doğrulanması, üretim birimlerinin emek-yoğun endüstrilerden sermaye ve kirlilik-yoğun endüstrilere kayması anlamına gelmektedir. Ancak KSH geçeli olmadığından, bu değişimler gevşsek çevre politikalarının üstünlüğüne bağlanamaz. Anlaşılan söz konusu değişim, Türkiye gibi gelişmekte olan ülkelerde sanayileşme hareketlerinin yalnızca emek-yoğun üretim tekniği ile sınırlı kalmayıp, yüksek oranda kirlilik yaratan sermaye yoğun endüstrilere doğru kaymaya başlamasından da ileri gelmektedir.

Elde edilen sonuçlara göre, yapısal değişimleri temsil eden imalat sanayinin, ekonominin ölçeğinin artışını temsil eden GSYH göre, $\mathrm{CO}_{2}$ 'yi daha yüksek oranda etkilediği görülmektedir. Sürdürülebilir iktisadi büyümeyi sürdürebilmek için, siyasi iktidarların imalat sanayinin üretiminde çevreye karşı duyarlı politikaların uygulanmasına çok daha fazla önem vermeleri gerekmektedir. Bununla birlikte, çevre unsurları göz ardı edilmeden DYSY'nın ülkeye sürekli olarak çekilmesini sağlayan politikaların uygulanması da gereklidir. Ayrıca toplumun çevre bilinci arttırılmalı ve kirlilik-yoğun malların üretiminde teknolojik gelişmeler yakından izlenerek mevcut çevre kirliliği azaltılmaya çalışılmalıdır.

\section{Kaynakça}

Alsan, M. \& D.E. Bloom \& D. Canning (2006), "The effect of population health on foreign direct investment inflows to low- and middle-income countries", World Development, 34, 613630.

Antweiler, W. \& R.B. Copeland \& M.S. Taylor (2001), "Is Free Trade Good for the Environment?", American Economic Review, 91(4), 877-908.

Cadarso, M.A. \& N. Gómez \& L.A. López \& M.A. Tobarra (2010), " $\mathrm{CO}_{2}$ Emissions of International Freight Transport and Offshoring: Measurement and Allocation", Ecological Economics, 69 (8), 1682-1694.

Chen, Z.M. \& G.Q. Chen (2011), "Embodied Carbon Dioxide Emission at Supra-National Scale: A Coalition Analysis for G7, BRIC, and The Rest of the World", Energy Policy, 39(5), 2899 -2909.

Chenery, H.B. \& M. Bruno (1962), "Development Alternatives in an Open The Economy: Case of Israel”, Economic Journal, 72(285), 79-103. 
Chenery, H.B. \& A.M. Strout (1966), "Foreign Assistance and Economic Development", American Economic Review, 56(3), 679-733.

Cole, M.A. (2004), "Trade, the Pollution Haven Hypothesis and the Environmental KUZNET Curve: Examining the Linkages", Ecological Economica, 48, 71-81.

Copeland, B.R. \& M.S. Taylor (2003), Trade and the Environment: Theory and Evidence, Princeton University Press. Princeton, USA.

Copeland, B.R. \& M. Scott Taylor (2004), “Trade, Growth and the Environment “, Journal of Economic Literature, 42(1), 7-71.

Cristea, A. \& D. Hummelsand \& L. Puzzelo (2011), “Trade and the Greenhouse Gas Emissions from International Freight Transport", paper presented at the ETSG Conference Copenhagen, Denmark.

Dean, J.M. (2002), “Does Trade Liberalization Harm the Environment? A New Test”, Canadian Journal of Economics, 35, 819-842.

Dickey D. \& W. Fuller (1981), "Likelihood Ratio Statistics for Autoregressive Time Series with a Unit Root”, Econometrica, 49, 1057-1072.

Dietzenbacher, E. \& K. Mukhopadhyay (2004), “An Empirical Examination of the Pollution Haven Hypothesis for India: Towards a Green Leontief Paradox?”, Presented in Input-Output and General Equilibrium: Data, Modeling and PolicyAnalysis, Brussels, Belgium.

Eskeland, G.S. \& A.E. Harrison (1997), "Moving to Greener Pastures? Multinationals and the Pollution-haven Hypothesis", World Bank Working Paper Series, N0.1744.

Friedl, B. \& M. Getzner (2003), "Determinant of CO2 Emissions in a Small Open Economy”, Journal of Ecological Economics, 45, 133-148.

Gay, W.P. \& L.R. Proops (1993), “Carbon-Dioxide Production by the UK Economy: An InputOutput Assessment”, Applied Energy, 44, 113-130.

GEMS (2012), Global Environmental Monitoring System Official Web Page, $<$ www.gemswater.org>.

Grossman, G.M. \& A.B. Krueger (1995),’Economic Growth and the Environment”, Quarterly Journal of Economics, 110, 353-77.

Grossman, G.M. ve A.B. Krueger (1993), "Environmental Impacts of a North American Free Trade Agreement", in Peter M. Garber (ed.), The US-Mexico Free Trade Agreement, Cambridge: MIT Press, 13-56.

Granger, C.W.J. \& R.F. Engle, (1987), “Co-integration And Error Correction: Representation, Estimation, and Testing", Econometrica, 55, 251-76.

Gujarati, D.N. (1999), Temel Ekonometri (çev. Ü Şenesen, G. G. Şenesen), İstanbul: Literatür.

Hayami H. \& M. Nakamura \& M. Suga \& K. Yoshioka (1997), "Environmental Management in Japan: Application of Input-Output Analysis to the Emission of Global Warming Gases", Managerial and Decision Economics, 18(2), 195-208. 
Hettige, H. \& M. Mani \& D. Whheler (1995), "Industrial Pollution in Economic Development: Kuznet Revisited" World Bank Policy Research Working Paper No.1876. Washington, DC: Retrieved on December 28, 2011, from the World Bank website: $<$ http://wwwwds.worldbank.org/servlet/WDSIBK>.

Kellenberg, D.K. (2009), “An Empirical Investigation of the Pollution Haven with Strategic Environment and Trade Policy", Journal of International Economics, 78, 242-255.

Kunce, M. et al (2002), "Environmental Policy and the Timing of Drilling and Production in the Oil and Gas Industry", in List, J. A. and A. de Zeeuw (ed.), Recent Advances in Environmental Economics, Edward Elgar, Cheltenham.

Letchumanan, R. \& F. Kodama (2000), "Reconciling the Conflict Between the Pollutionhaven Hypothesis and an Emerging Trajectory of International Technology Transfer", Research Policy, 29, 59-79.

Levinson, A. (2003), "Environmental Regulatory Competition: A Status Report and Some New Evidence”, National Tax Journal, 56, 91-106.

Levinson, A. (1997), “A Note on Environmental Federalism: Interpreting Some Contradictory Results", Journal of Environmental Economics and Management, 33, 359-366.

Levinson, A. (2008), Pollution Haven Hypothesis, New Palgrave Dictionary of Economics, 2nd Edition.

List, J. A. et al (2003), "Effects of Environmental Regulations on Manufacturing Plant Births: Evidence from a Propensity Score Matching Estimator", Review of Economics and Statistics, 85(4), 944-952.

Lofdalh, C.L. (2002), Environmental Impacts of Globalisation and Trade: A systems study, The MIT Press, Cambridge, Massachusetts.

Low, P. \& A. Yeats (1992), "Do 'Dirty' Industries Migrate?” in International Trade and the Environment, Patrick Low (ed.), International Trade and the Environment, Washington, DC, 89-104. World Bank Discuss paper 159.

Lucas, R.E.B. \& D. Wheeler \& H. Hermamala (1992), "Economic Development, Environmental Regulation and the International Migration of Toxic Industrial Pollution: 1960-1988", in Patrick Low (ed.), International Trade and the Environment, Washington, DC, 67-86. World Bank Discussion paper 159.

Machado, G. \& R. Schaeffer \& E. Worrell (2001), "Energy and Carbon Embodied in the International Trade of Brazil: An Input-Output Approach", Ecological Economics, 39(3), 409-424.

Mani M. (1996), "Environmental Tariffs on Polluting Imports: An Empirical Study”, Environmental and Resource Economics, 7, 391-411.

Mani, M. \& D. Wheeler (1997), "In Search of Pollution Havens? Dirty Industry Migration in the World Economy", World Bank working paper 16. 
Mani M. \& D. Wheeler (1998), "In Search of Pollution Havens? Dirty Industry in the World Economy 1960 to 1995”, The Journal of Environment and Development, 7(3), 215-247.

Merican, Y. \& Z .Yusup \& Z.M. Noor \& L.S. Hook (2007), "Foreign Direct Investment and Pollution in Five ASEAN Nation" Journal of Economics and Management, 1(2): 245 261.

McKinnon, R.I. (1964), "Foreign Exchange Constraints in Economic Development and Efficient Aid Allocation", Economic Journal, 74(294), 388-409.

Mukhopadhyay, K. \& O. Forssell (2004), “An Empirical Investigation of Air Pollution from Fossil Fuel Combustion and its Impact on Health in India during 1973-1974 to 1996-1997”, Ecological Economics, 55(2), 235-250.

OECD (1997), Globalisation and Environment: Preliminary Perspectives, Paris.

Palmer, K et al (1995), "Tightening Environmental Standards: The Benefits Cost or the No-Cost Paradigm?”, Journal of Economic Perspectives, 9(4), 119-132.

Phillips, P.C.B. \& P. Perron (1988) “Testing For A Unit Root in Time Series Regression”, Biometrika, 75, 335-346.

Porter, G. (1999), "Trade Competition and Pollution Standards: Race to the Bottom or Stuck at the Bottom? ", Journal of Environment and Development, 8 (2), 133-151.

Proops, J.L.R. \& G. Atkinson \& B.F. Schlotheim \& S. Simon (1999), "International Trade and the Sustainability Footprint: A Practical Criterion for its Assessment”, Ecological Economics, 28, 75-97.

Raspiller, S. ve N. Riedinger (2004), "Do Environmental Regulations Influence the Location Behavior of French Firms?", Paper Presented at the Thirteenth Annual Conference of the EAERE, Budapest, Hungary.

Ridzuan, A.R. \& A.H.M. Noor \& E.M. Ahmad (2012) "FDI Impact on Carbon Dioxide Emission in ASEAN 5", 2nd Annual Summit on Business and Entrepreneurial Studies (2nd ASBES 2012), 471-484.

Rock, M.T. (1996), "Pollution Intensity of GDP and Trade Policy: Can the World Bank be wrong?", World Development, 24, 471-479.

Shadbegian, R \& A.Wolverton (2010), "Location Decisions of U.S. Polluting Plants: Theory, Empirical Evidence, and Consequences", International Review of Environmental and Resource Economics, 1, 1-49.

Talukdar, D. \& C.M. Meisner (2001), "Does the Private Sector Help or Hurt the Environment? Evidence From Carbon Dioxide Pollution in Developing Countries", World Development, 29 (5), 827-840.

Taylor M.S. (2004), "Unbundling the Pollution Haven Hypothesis", Advances in Economic Analysis and Policy, 4(2), 1-30. 
Temurshoev, U. (2006), "Pollution Havean Hypothesis or Factor Endowment Hypothesis: Theory and Empirical Examination for the Us and China”, CERGE-EI, Working Paper Series 292, 1-51.

Tobey, James A. (1990), “The Effects of Domestic Environmental Policies on Patterns of World Trade: An Empirical Test”, Kyklos, 43(2), 191-209.

World Bank (2012), World Bank Group Official Web Page, <www.worldbank.org>.

Wyckoff, W.A. \& J.M. Roop (1994), "The Embodiment of Carbon in Imports of Manufactured Products: Implications for International Agreements on Greenhouse Gas Emissions", Energy Policy, 22(3), 187-194.

Xing, Y. \& C.D. Kolstad (2002), “Do Lax Environmental Regulations Attract Foreign Investment? “, Envirnomental and Resource Economics, 21, 1-22.

Xu, X. (1999), "Do Stringent Environmental Regulations Reduce the International Competitiveness of Environmentally Sensitive Goods? A Global Perspective”, World Development, 27(7), 1215-1226. 
EK: 1

Tablo: 8

\section{Zaman Verilerinin Birim Kök Test Sonuçları (Sabit Terimli ve Trendli)}

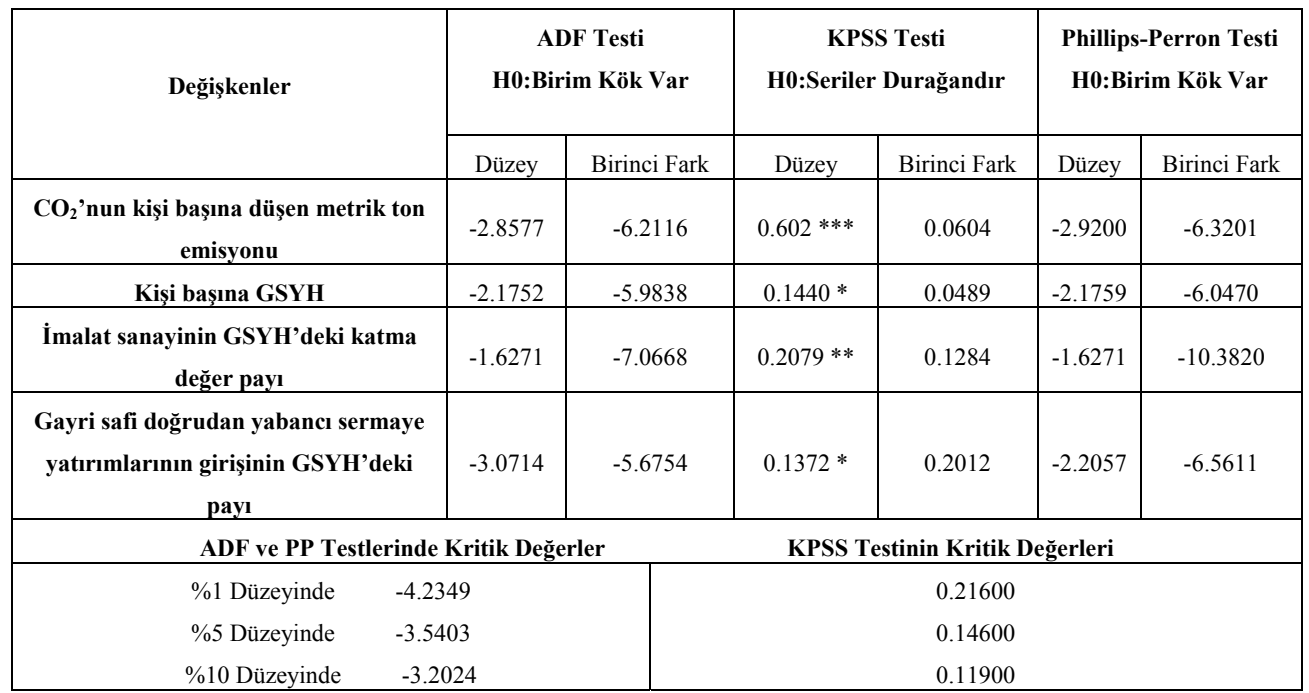

***0.01 düzeyinde, **0.05, *0.1 düzeyinde anlamlılı̆̆ ifade etmektedir. 